\title{
ÖLÜM YOLUNDA İKİ ŞÂİR, BİR ÂŞIK'
}

\section{Yasemin AKKUŞ ${ }^{2}$}

\begin{abstract}
$\ddot{O} \mathbf{z}$
Klasik İran edebiyatının en önemli şairlerinden Nizâmî, 'Leylâ ve Mecnûn' adlı dillere destan bir aşk hikâyesini ölümsüzleştirmeyi başarmıştır. 12. yüzylda, Nizâmî’nin üslûbuyla dirilen bu hikâye, yüzyllarca gerek İran gerekse Türk edebiyatında birçok şairin kalemiyle yeni bir soluk kazanmıştır. Söz konusu eser, şüphesiz 16. yüzyl Klâsik Türk edebiyatı şairi Fuzûlî̉nin fesahat, belagat ve üslûbuyla zirveye çıkmıştır. Nizâmî ve Fuzûlî’nin 'Leylâ ve Mecnûn' mesnevileri, mukayese edilmeye layık iki eser olarak her zaman araştırmacıların gündeminde olmuştur. Fakat şu ana kadar yapılan Nizâmî-Fuzûlî mukayeselerinde genellikle yatay karşlaş̧tırmalar söz konusu edilmiş, iki eser ve şairleri arasındaki farklılık ve benzerliklerin her yönüyle ortaya konduğu dikey bir karşılaştırma yapılmamıștır. Bu çalışmada, Leylâ'nın ölümüyle birlikte vukû bulan Mecnûn'un ölüm sahnesi mukayese edilecektir. Nizâmı̂’nin, eserinde sadece olayı aktardığı görülmekteyken Fuzûlînnin ise kahramanlarının bilinçaltını ve içinde bulundukları ruhsal haleti tasvir ettiği; araya serpiştirdiği gazellerle duyguyu ön plana çıkararak, olayı daha da insanîleştirdiği görülmektedir. Nizâmî̀de vak'anın öncelendiği, Fuzûlı̀’de ise olay-insan ilişkisinin derinlemesine işlendiği ve hikâyeciliğin ön plana çıktığı dikkat çekmektedir.
\end{abstract}

\section{TWO POETS, ONE LOVER ON THE WAY TO DEATH}

\begin{abstract}
Nizami, one of the most important poets of classical Iranian literature, succeeded in immortalizing a proverbial love story named 'Layla and Majnun'. This story, which rose with the tone of Nizami in 12th century, achieved a new inspiration in both Iranian and Turkish literatures by many poets for centuries. The work of art in question came to a height undoubtedly by the fluency, declamation and style of Fuzuli, who was a poet of 16th century Classical Turkish literature. 'Layla and Majnun' masnavis of Nizami and Fuzuli have always been in the agenda of researchers as two creations worth comparison. However, generally horizontal comparisons have been mentioned in the Nizami-Fuzuli comparisons done until now; a vertical comparison has not been conducted, which puts forward differences and similarities between two creations and their poets at all points. In this study, death scene of Majnun, which takes place together with the death of Layla, will be compared. While Nizami is seen to narrate only the incident in his work; Fuzuli is seen to describe the subconscious and the emotional state his characters are in and to humanize the event by featuring the emotion he interspersed among via lyrics. Prioritization of the event in Nizami attracts attention; while eventhuman relationship to be cultivated deeply and storytelling coming to prominence stands out in Fuzuli.
\end{abstract}

Key Words: Comparison, Nizami, Fuzuli, Layla, Majnun, Death

Bu makale, Akademik Girişim Platformu tarafından 4-7 Şubat 2016 tarihlerinde Barselona'da gerçekleştirilen "Sosyal Bilimler Kongresi”nde sunulmuș olan bildirinin genişletilmiș șeklidir.

Yrd. Doç. Dr., Karamanoğlu Mehmetbey Üniversitesi, Edebiyat Fakültesi, Türk Dili ve Edebiyatı Bölümü, yaseminakkus@kmu.edu.tr [Makale kayıt tarihi: 9.3.2017-kabul tarihi: 11.4.2017]. 


\section{Giriş}

Edebî metin mukayesesi, birbirinden farklı metinlerin yapısı, muhtevası, yansıttı̆̆ı zihniyet, insan ve toplum anlayışı, inançları, edebiyat geleneği gibi açılardan karşılaştırılmak amacıyla yapılır. Her dönem ve edebiyat muhiti, metinlerinde kendi dönemlerinin özelliklerini yansitırlar.

"Edebî duyguların incelenmesi, edebiyattaki duyguların incelenmesini tamamen aşar. Bu durumda erdem, mutluluk, ölüm, suç, özgürlük vb. yazarın mizacına göre” (Rousseau, 1994, s. 139) değişkenlik gösterir. Duygunun fiilî görünüm ve biçimi yazılı bir geleneğe, bir üslûba, bir modaya bağlıdır. Duygusallığın olağan incelenmesine içtenliğin incelenmesini de eklemek gerekmektedir. Duygular da düşünceler gibi, ülke ve uygarlıklar arasında gidip gelir, değiş tokuş yapar ve kılık değiştirirler (Rousseau, 1994, s. 140).

Böyle bir mukayesede, dikkat edilmesi gereken üç husus şöyledir: Yazarın özgün mizacının payı, onu kuşatan toplumun etkisi ve kaygıların dile getirilişine has edebî geleneğin ağırlığı. (Rousseau, 1994, 141) $\mathrm{Bu}$ çalışmada, mukayeseli edebiyatın amacına uygun bir şekilde, birbirinden farklı zaman ve dillerde yazılmış iki Leylâ ve Mecnûn hikâyesinin mukayesesi yapılacaktır. Birisi ilk manzum ve Farsça Leylâ ve Mecnûn metni olan Genceli Nizâmî (1141-1204)'nin metni; diğeri de Fuzûlî(1483-1556)'nin Türkçe kaleme aldığı metindir.

İslâmî edebiyatın en çok işlenen konularından biri de başlangıcı Asurlulara kadar giden Leylâ ve Mecnûn hikâyesidir. Asur kralı Asurbanipal'ın kitaplığındaki çivi yazılı tuğla tabletlerde bu hikâyeye rastlanmıştır. Arap yarımadasında yüzyllar boyunca yaşayan hikâye, hicri 1. yüzyllda Âmirî kabilesinden Kays bin el-Mülevvah adlı bir şairin, amcasının kızı Leylâ binti Mahdî bin Sa'd için söylediği aşk şiirleri ile gelişmiştir. Bu şiirler yayılarak dilden dile yayılmaya başlamış ve kısa bir süre içinde Arap yarımadasında yaşayan hikâyeyle beslenerek son şeklini almıştır. (İpekten, 2015, s. 43) Leylâ ve Mecnûn hikâyesi, Arap edebiyatında 10. yüzyıldan beri yaygındır. Mecnûn'a atfedilen şiirler, aralarına katılan mensur parçalarla birlikte birbirine bağlanarak bir hikâye haline sokulmuş ve türlü adlar altında toplanmıştır (Levend, 1959, s. 6).

\section{Nizâmî'nin Leylâ ve Mecnûn'u}

'Leylâ ve Mecnûn' hikâyesini İran şairleri daha ayrıntılı işlemişlerdir. Önce başka eserler içinde parça parça görülen bu hikâye, ilk kez Nizâmî tarafından tam bir mesnevi haline getirilmiş ve tasavvufî unsurlar eklenmiştir. İran edebiyatında kaleme alınmış 'Leylâ ve Mecnûn' hikâyelerinden en başarılısı Nizâmîye ait olanıdır (İpekten, 2015, s. 43).

Nizâmî, Klasik Fars edebiyatının dâhi şairlerinden biri olarak tanınmasının yanı sıra hamse türünün kuruculuğu payesini elde etmiştir (Kanar, 2007, s. 183). Kendini "sonsuz söz sihirbazı ve eşi benzeri olmayan" manasında "âyîne-i gayb" (Servetiyân, 1376, s. 17) yani "gaybın aynası" olarak adlandıran Nizâmî, eserini Şirvanşahlardan Ahistan bin Minuçihr'in isteği üzerine 1188 tarihinde kaleme almıştır. Böylece 4718 beyitlik mesnevisini 1188 yllında tamamlamıştır (Levend, 1959, s. 11). Nizâmî, Arap kaynaklarındaki söylentilerden bazısını değiştirmiş, kendiliğinden bazı motifler de ekleyip konuya uygun hikâyelerle süslemiş (Levend, 1959, s. 31) ve tasavvufla renk katarak eserini meydana getirmiştir. (Servetiyân, 1376, s. 192) Klasik Fars edebiyatında Nizâmî'den itibaren büyük ilgi gören Leylâ ve Mecnûn mesnevisi birçok şair tarafından kaleme alınmışsa da hiçbiri onun seviyesine ulaşamamıştır (Yazıc1, 2003, s. 160). 


\section{Fuzûlî'nin Leylâ ve Mecnûn'u}

Fuzûlî, 16. yüzyıldan bugüne kadar yetişen, Türk edebiyatının tanınmış şairleri içerisinde en büyük lirik şair olarak yer edinmiştir. Aşk ve ıztırap şairi olarak bilinen Fuzûlîye göre gerçek şiir, dertten ve elemden bahseden şiirdir. Şair, şiirlerinde terennüm ettiği aşkını 'Leylâ ve Mecnûn' mesnevisinde hikâyelendirmiş ve sanki kendi duygularını bu iki kahramana söyletmiştir. Fuzûlî’nin 'Leylâ ve Mecnûn'unun Türk edebiyatında yazılmış bütün 'Leylâ ve Mecnûn'lardan üstün ve güzel oluşu bu yüzdendir (Mazıŏ̆lu, 1992, s. 13-21).

Fuzûlî ‘Leylâ ve Mecnûn' hikâyesini yazmaya 1534 yllında Kanuni Sultan Süleyman ile beraber Bağdat’a gelen Taşlıcalı Yahya ve Hayâlî Bey’in teşviki ile karar verdiğini eserinde belirtmiştir. Şair, Türk edebiyatında en çok okunan 3096 beyitlik 'Leylâ ve Mecnûn' adlı mesnevisini 1535 yllında tamamlayarak Bağdat Valisi Veys Bey'e ithaf etmiştir. Bölüm başlıkları secili nesir ile ifade edilen eserin içine serpiştirilmiş rubailer, gazeller ve murabbalar vardır. Gazellerden 10'u Leylâ, 14'ü Mecnûn tarafından, diğerleri ise üçüncü şahıs ağzıyla söylenmiştir (Açıgöz, 1998, 21). Fuzûlî, hikâyeyi meydana getirirken Nizâmînin mesnevisini esas almıştır (Levend, 1959, s. 267).

\section{3. 'Leylâ ve Mecnûn' Hikâyesinin Özeti}

'Leylâ ve Mecnûn' hikâyesinin konusu iki şairde birtakım farklılıklar gösterse de ana hatlarıyla kısaca şöyledir:

Zengin bir Arap beyinin oğlu olan Kays ile Leylâ okudukları mektepte karşlaşır ve birbirlerine âşık olurlar. Leylâ'nın annesi, çıkan dedikodulardan sonra Leylâ'yı okuldan alır. Bu ayrılık üzerine Kays derdini saklamaz, halka rüsva olur, 'Mecnûn' diye anılmaya başlar ve çöllere düşer. Babası Mecnûn’u bu sevdadan vazgeçirmek için nasihatler eder, bu dertten kurtulmak üzere Allah'a yalvarması için Kâbe'ye götürür. Fakat Mecnûn, Kâbe'de Allah’tan aşk derdini arttırmasını ister. Babası çaresiz ve perişan eve döner, Mecnûn ise arkadaş edindiği vahşi hayvanların yanına çöle döner.

Daha önce Leylầyı ailesinden isteyen Mecnûn'un babasına cevap olarak; kızlarını böyle bir çılgına vermeyecekleri, söylenmiştir. Leylâ'yı İbn-i Selâm adında zengin bir adamla evlendirirler. Leylâ, kocasına yalanlar söyleyerek kendisine yaklaştırmaz. Bir müddet sonra İbn-i Selâm ölür. İki âşık arasında haber getirip götüren Zeyd ile bu iki âşığı kavuşturmak için savaşan Nevfel de sonucu değiştiremez. Mecnûn, çölde aşkın bütün cefa ve ıztıraplarını yalnız başına yaşar. Leylâ, bu aşk acısına daha fazla dayanamaz ve ruhunu teslim eder. Leylâ'nın ölüm haberini alan Mecnûn, sevgilisinin kabrinin üzerine kapanarak oracıkta can verir.

\section{Nizâmî ve Fuzûlî’de Olay Örgüleri}

Şöhretleri kendi edebiyatları dışına taşan Nizâmî ve Fuzûlîyi, söz konusu hikâye çerçevesinde birçok araştırmacı, farklı zaviyelerden mukayese etmiştir. Fakat dikey karşılaştırma ile yani; benzerliklerin ve farklılıkların ayrıntılı bir şekilde ele alındığı, şairlerin sadece hikâyeyi işleyişi değil aynı zamanda kendi kültürü ve lisanının bir aksi olarak yansıttı̆̆ı bakış açısı, kurgulama yöntemi, üslup ve anlatımının 
Two Poets, One Lover on The Way to Death / Y. Akkuş (p. 21-36)

irdelendiği bir mukayese şekli ortaya konmamıştır. Bu tür bir dikey karşlaş̧ırma33, epey ayrıntı içereceğinden ötürü hikâyenin sadece bir bölümü üzerinde uygulanacaktır.

Mecnûn'un ölüm sahnesi, hikâyenin sonu ve aynı zamanda en etkileyici bölümlerinden bir tanesidir. Tabii, bu arada Mecnûn'un ölüm sahnesini hazırlayan diğer olay örgüleri de önem arz etmektedir. Bunlar; Leylâ'nın kocası İbn-i Selâm'ın ölümünden sonra iki âşı̆̆ın çeşitli nedenlerle yine kavuşamaması ve Leylâ’nın ölümü, şeklinde gelişen olay örgüleridir. Her iki şairde birtakım farklılık ve benzerlikler barındıran bu sahneler, ana hatlarıyla aynılık gösterirler.

Nizâmî'de4 söz konusu olay örgüleri şöyledir:

- Leylânın kocası İbn-i Selâmın vefat etmesi

- Hazan tasviri ve Leylânın ölümü

- Leylânın ölümüne Mecnûnun ağlayıp inlemesi

- Leylânın kabri üzerinde Mecnûnun vefat etmesi

- Kabilesinin Mecnûnun ölümünden haberdar olması

Fuzûlî'de5 Mecnûn'u ölüme hazırlayan olay örgüleri şunlardır:

- Bu Leylînün İbn-i Selâmdan sonra mâcerâsıdur ve zâviye-i mihnetde vâki' olan belâsıdur

- Bu Leylînün nâkaya arz-ı râzıdur ve zebân-ı hâl ile izhâr-ı niyâzıdur

- Bu Leylînün Mecnûndan haberdâr olduğıdur ve metâ'-ı vaslına nakd-i cân ile harîdâr olduğıdur

- Bu Mecnûnun nihâyet-i hayretidür ve Leylîden istiğnâ vü gafletidür

- Bu Leylîye Mecnûnun istiğnâsıdur ve isbât-ı safâ-yı imlâsıdur

- Bu Leylîden Mecnûn etvârına tahsîndür ve hüsn-i i’tikâdına kemâl-i yakîndür

- Bu Mecnûnun mi'râc-ı fezâilidür ve beyân-ı mertebe-i hüsn-i hasâilidür

- Bu Leylînün bahâr-ı ömrine hazân erdüğidür ve gülbün-i hayâtına sarsar-ı noksân yetdüğidür

- Bu Leylînün anasına vasiyyet etdüğidür ve dûst yâdiyle dünyâdan getdüğidür

- Bu Mecnûnun Leylî vefâtından haber eşitdüğidür ve hasretle dünyâdan getdüğidür

Her iki şairin eserinde, sadece olay örgülerini ihtiva eden başlıklar mukayese edildiğinde bile Fuzûlî̀nin Nizâmîye nispetle tahkiye etmede daha başarılı olduğu anlaşılmaktadır. Nizâmî, bazı vaka zincirlerini ayrı ayrı ele almaktansa bir arada işlemeyi uygun görmektedir. Fuzûlî ise her birini ayrı başlıklar altında işlemekte ve "metin halkasındaki hale münasip gazeller ile fiktif yapının" (Açıgöz, 1987, s. 40) daha

3 'Dikey' ve 'yatay' karşılaștırma ifadeleri daha önce herhangi bir çalışmada bilimsel bir terim olarak kullanılmamıştır. 'Yatay karşılaştırma' ile yüzeysel, ayrıntılara değinilmemiş ve genel hatlarıyla yapılan bir mukayese, 'dikey karşlaştırma' ile metnin kendi içinde bütünlük arz eden bỉr bölümü üzerinde ve her türlü ayrıntıya girilerek yapılmış bir mukayese kastedilmektedir.

4 Nizâmı̂’nin "Leylî vü Mecnûn” adlı eserinden yapılan alıntılarda şu eser kaynak olarak alınmıştır: "Hasan Vahid Destgerdi-Saîd Hamidiyân, Hakîm Nizâmî Genceî Leylî vü Mecnûn, Neşr-i Katre, Tahran 1389." Fuzûlî̀nin "Leylâ vü Mecnûn” adlı eserinden yapılan alıntılarda şu eser kaynak olarak alınmıştır: "Necmettin Halil Onan, Fuzûlî Leylâ ile Mecnûn, Maarif Basımevi, İstanbul 1956." (Ayrıca diğer kaynaklar da kontrol amaçlı kullanılmıştır: "Hüseyin Ayan, Leylâ vü Mecnûn/Fuzûlî, Dergâh Yayınları, İstanbul 2014.", "Muhammet Nur Doğan, Fuzûlî Leylâ ve Mecnûn, Yelkenli Yayınları, İstanbul 2015”) 
kolay anlaşılmasına vesile olmaktadır. Bu da şairin anlatım tekniğini; yani yoğun tahlil ve tasvir anını nasıl şekillendirdiğini anlatmaktadır.

\section{Olay Örgülerinin Genel Mukayesesi}

Fuzûlî ve Nizâmî'de Mecnûn'un ölüm sahnesini mukayeseye geçmeden evvel yukarıda başlık olarak verilen olay örgülerinin içeriklerine değinmek yerinde olacaktır. Söz konusu başlıklar, birebir örtüşmediğinden bu bölümlerin özet karşılaştırması ana hatlarıyla ve hikâye odaklı yapılacaktır:

\subsection{Leylâ'nın Kocası İbn-i Selâm'ın Ölümünden Sonra:}

Nizâmî’nin mesnevisinde, kocası İbn-i Selâm’nn ölümünden sonra Leylâ, uzun süre evden çıamaz. Çünkü Arap âdetlerine göre kocası ölen kadının iki yıl boyunca evden dışarı çıkmaması ve yüzünü kimsenin görmemesi gerekmektedir. Fakat Leylâ'nın aklı ve gönlü Mecnûn'dadır. Sevdiğine ulaşmak, onu görmek ister. ${ }^{6}$ Bu ayrılık acısı Leylâyıı iyice güçsüz bırakır ve zayıf düşürür.

Fuzûlî̀nin eserinde ise İbn-i Selâm'ın ölümünden sonra Leylâ, baba evine döner. Ağlar, yas tutar; fakat bu ağlayışlar aslında Mecnûn içindir. Feleğe, talihine isyan eder. Bir yandan Mecnûn'la birlikte olduğu takdirde namusuna leke sürüleceğini düşünür, diğer yandan da Mecnûn'un âhından çekinir. Ne yapacağını bilemez ve Allah'tan kendisini hidayete erdirmesi için dualar eder. Devesiyle dertleşir, sırrını açar, hâlini izhar eder ve devesinden kendisini Mecnûn'un yanına götürmesini ister. Leylâ, bir ara kendinden geçer. Bu arada gecenin karanlığında kafileden uzaklaşırlar ve kervancı başının bundan haberi olmaz. Leylâ, kendine geldiğinde yoldaşlarının gittiğini fark eder, onlardan bir iz arar fakat bulamaz. Mecnûn'un diyarına düşen Leylâ, ansızın hüzünlü birini görür. "Kimsin?" diye seslenir. Konuşurlar, Leylâ önceleri Mecnûn'u tanımaz. Yaşadıklarını bir bir anlatan Mecnûn, şiir söyler. Bunun üzerine Leylâ, onu tanır ve kendi hâlinden bahseder. Şimdiye kadar hep intizar çektin, yâri görmeyi diledin, artık ona kavuştun, diyerek Leylâ da bir şiir söyler. Lakin Mecnûn, Leylâ'yı tanımaz. Aklı başında olmadığı için tanımadığını söyler ve "Sen kimsin?" diye sorar. Leylâ, kendisinin sevdiği kız olduğunu müjdeler, visale davet eder, âşığın maşuka naz ettiği nerde görülmüştür, diyerek sitemler eder. Mecnûn ise hayalinle yeterince yandığını ve artık visale takati kalmadığını, kendisinin bu aşk yolunda mecnun olduğunu söyler. Leylâ'ya akıl yolunu tutup kendi durumuna düşmemesi ve namusunu koruması için nasihatler eder. Vahdet yolunda "ben-sen" olmayacağını ve rüsvalık yolunu tuttuğunu dile getirir. Mecnûn'un ilâhî aşka eriştiğini anlayan Leylâ, şöyle der: "Hoş mertebedir, bu; bârek’Allâh! Üzgündüm; ama beni mutlu ettin, gafildim ve cehaletimle mest idim, süslenip seni hayal ederdim. Oysa şimdi senin hâlini anladım. Ben artık bundan sonra yüzüme yokluk örtüsünü çekeyim.” Devesinin hızla kendine doğru geldiğini görür. Mecnûn, gamlı bir hâlde geride kalırken devesi Leylâyı evine götürür. Mecnûn'dan uzaklaşıp vuslatta teselli bulamayan Leylâ, dünyayla olan tüm ilişkisini keser, matemdedir, perişan olur.

6 Eserin bu bölümünde Nizâmîye ait olup olmadığı belli olmayan ve Şair-i ilhâkî adıyla yazılmış bazı ilaveler mevcuttur. Bu ilâvelere göre; Leylâ iki yıl matemden sonra baba evine döner, artık kimseden korkusu yoktur. Zeyd’i çă̆ırarak Mecnûn'u görmek istediğini söyler ve ondan Mecnûn'u getirmesini rica eder. Mecnûn bu müjdeyi alınca sevinir, Leylâ'nın gönderdiği elbiseleri giyer. Vahşi hayvanlar peşlerinde Zeyd ile birlikte yola çıkarlar. Geldiklerini gören Leylâ, çadırından çıkarak misafirinin ayağına kapanır. İki sevgili kendilerinden geçerler. Nihayetinde iki sevgili sarmaş dolaş olurlar ve bu şekilde bir gün bir gece kalırlar. (Destgerdî, Hamidiyân 1389: 240-247) 


\subsection{Leylâ'nın Sırrını Annesine Açması, Vasiyeti ve ölümü:}

Nizâmî’nin Leylâ’sı, annesinin yanına giderek sırrını açar ve şöyle der: "Bundan sonra sevdiğim sana yadigâr, sakın ona kötü gözle bakma, benim gibi sen de onu yücelt. O gönül hastasına şöyle dersin: 'Leylâ ölüm anına kadar seni ve aşkını sayıkladı, senin hatıranla can verdi, azığı sadece aşk derdiydi, öldükten sonra da gözleri yolda senin gelmeni bekleyecek.' Öldüğ̈̈m zaman onun yolunun tozundan gözüme sürme çek. Sevgilim mezarıma gelip ağlayacaktır. Onu hoş tut, benim hâlimi ona anlat. ” Daha sonra ise annesinden gül renkli kefenle kendisini gelin gibi uğurlamasını ister ve ebedî huzura kavuşarak can verir. Kızının cansız bedenini gören Leylâ'nın annesi, yüreğindeki yangınla saçlarını yolar, gözyaşı döker. Tüm bu feryatlardan sonra -kızının vasiyet ettiği gibi- gelinin cansız bedenini anber ve gül suyuyla ylkayıp toprağa verir.

Fuzûlî’nin günden güne eriyen Leylâ'sı, gizlediği ve tahammül ettiği derdini, sırrını annesine açar. Bir ay yüzlüye müptelâ olduğunu, ancak bu aşktan pişman olmadığını söyler. Ve şöyle devam eder: “Bu dünyaya veda ettiğimde $o$, bensiz ağlayıp inleyecek. Eğer onun bulunduğu yere yolun düşerse sevgiliden benim için dua iste, ayaklarına kapan. Leylâ senin yolunda can verdi, özgür ve mutlu oldu, sen de bu yolda sadıksan bu dünyayı terk etmek için sabretme, dersin." Leylâ bu sözleriyle vasiyetini tamamlar ve ebedî yolculuğa çıkar. Annesi, sensiz ne yaparım, diyerek kanlı gözyaşları döker.

\section{Mecnûn'un Ölüm Sahnesi}

Leylâ’nın ölümünden sonra gerçekleşen bu olay örgüsü, aynı zamanda hikâyenin son sahnesidir. Mecnûn'un ölümünün anlatıldığı bu bölüm, dikey bir mukayese ile ele alınarak neredeyse beyit beyit karşılaştırılacaktır.

\subsection{Nizâmî'de Mecnûn'un Ölüm Sahnesi}

Nizâmî’de ölüm sahnesi şu şekilde verilmiştir: Leylâ'nın ölüm haberini duyan Mecnûn, feryat ederek Leylâ’nın kabrine koşar, amansız gözyaşları döker, ağlar, inler, bulutlar gibi için için gürler. O kan dalgasına benzeyen kabrin üzerindeki Mecnûn'un halini sorma. Öyle çok kanlı gözyaşı döker ki insanlar onu görmeye dayanamayıp kaçar. Leylâ'nın mezarı üzerinde kederinden öyle bükülmüsstür ki tıpkı hazinenin üstündeki yılan gibidir. Öyle çok lâle renkli (kanlı) gözyaşı döker ki kabrin üstündeki yeşil otlardan lâle çıkar:

Ez-bes ki sirişk-i lâle-gûn riht

Lâle ze-giyâh gûreş engiht $\quad(255 / 5)^{7}$

Kanlı ciğeri mum gibi erimiş, ateşli dili çözülmüştür, o an derdinden ağlayarak söylemeye başlar: "Ey hazan vurmuş taze gül, dünya yüzü görmeden dünyadan göçen! Nasılsın? Toprak eziyet ediyor mu? Bu karanlık mezarda ne yapıyorsun? Misk tanesi gibi ben'in, o âhû gözlerin ne hâlde? Parlak akik gibi kıpkırmızı dudakların, misk kokan kıvırcık saçların ne hâlde? Hangi gözler, görüyor seni; hangi dimağlara misk kokunu saçıyorsun? Servi boyunla hangi ırmağın kenarında salınırsın? Meclisin hangi lâle bahçesindedir? Bu diken rahatsız ediyor mu, seni? Bu mağaranın içinde neler yapıyorsun? Mağaralarda daima yllanlar olur, ey ay yüzlü bu mağara sana mekân olur mu?

7 Nizâmî’nin mesnevisinden yapılan alıntılarda kaynak olarak kullanılan kitapta beyit numarası her sayfada yeniden başladığı için parantez içinde verilen sayıların ilki sayfa numarası, ikincisi o sayfadaki beyit numarasidır. 
Der-gâr hemîşe cây-ı mâr est
Ey mâh to-ra çi cây-ı gâr est $\quad$ (257 / 10)

Senin bu mağarada olman beni derbeder ediyor, nasıl dayanayım buna, sen benim dostum, sevgilimsin. Sen bir hazine olduğun için toprağın altındasın; eğer öyle olmasaydı, orada ne işin vardı? Mağaraların içinde saklı her hazinenin kenarına bir yılan çöreklenir. Ben yuvasız bir yılan misali senin toprağının üzerinde hazine bekçisiyim. Yoldaki kumlar gibi divaneydin, çılgındın; şimdi ise kuyunun içindeki su gibi huzura erdin:

Şûrîde budi çü rîg der-râh

Âsûde şodi çü âb der-çâh

$(257 / 25)$

Ay misali gurbette olmak, kimsesizlik senin kısmetindir ve ay’ın kimsesizliği garip bir şey değildir. Görünüşte yoksun, kayıpsın; aslında canımın ta içindesin. Dertli gözümden uzaklaşsan da gönlümden uzak değilsin. Suretin aradan çekilse de aşkının derdi sonsuzdur.”

Bu cümleleri söyler, ağlar ve dövünür. Önünde ve arkasında bir avuç vahşi hayvanla kendi diyarına doğru yola çıar. Ayrılık üzerine beyitler okuyup ölüm dansı içinde devesini sürer. Ayrılı̆̆ı ve vefayı öyle tasvir edip anlatır ki geriye söylenmedik söz bırakmaz. Esefle başını taşlara vurur, gözyaşıyla kumlara renk verir. Geçtiği yollarda gönlünden çıkan kıvılcımlarla tutuşmayan diken, kanıyla boyamadığı taş kalmaz.

Ağlamaktan mecalsiz kalan Mecnûn, sevgilisini görme arzusuyla kalkar. Dağdan inen sel misali Leylâ'nın kabrine gider. Mezara başını koyar ve toprağını binlerce kez öper. O vefalı sevgilinin mezarıyla ağlayarak gönül derdini paylaşır. Bu arada vahşi hayvanlar da Mecnûn'un etrafında durmuştur. Mecnûn gözyaşlarıyla bir zemzem kuyusu, vahşi hayvanlar ise harem(Ka'be)in etrafını çevrelemiş gibidir. Gözlerini yoldan ayırmazlar ve Mecnûn'un yanına kimseyi sokmazlar:

Çeşm ez-reh-i u codâ ne-kerdend

Kes râ ber-i u rehâ ne-kerdend (259 / 2)

Kuştan karıncaya kadar hiç kimse mezarın yanına yaklaşamaz. İki üç gün o köyün köpekleriyle ıztırap içinde yaşar. Kimi zaman sevgilinin mezarını kendine kıble yapar, kimi zaman da çöllerde dolaşır. Karıncanın gözünü mekân edinir, mezar mezar dolaşır. Ve sonunda bu acı karşısında biçare kalır, o da göçüp gider.

Zamanın tükenmiş, yanık âşığını ve döktüğü gözyaşlarını felek değirmeni öyle öğütür ki zavallı âşık daha da çaresiz kalıverir. Canı burnunda, ağlayıp dertlendiği bir gün toprağın gelinine (Leylâ'nın mezarı) doğru gelir. Mezarın üstüne düsser, gemisi karanlık sulara gömülür. Yorgun bir karınca gibi yuvarlanır, yaralı bir yılan gibi kıvranır. Ağlaya inleye iki üç beyit okur, acı acı iki üç damla gözyaşı döker:

\section{Beyt-i do se zâr zâr ber-hând}

Eşk-i do se telh telh be-feşând (264 / 9)

Mecnûn, ellerini semâya doğru açar, gözlerini kapar ve şöyle dua eder: "Ey her şeyi yaratan Hâlık! Beni bu mihnetten kurtar ki sevdiğime kavuşayım. Ruhumu özgür bırak, canımı al; bu sıkıntılardan beni kurtar." Başını yere koyar, mezarı kucaklar. "Ey dost/sevgili” der ve can verir. O da bu geçitten (dünyadan) geçer. Bu yoldan geçmeyen var mıdır? Yokluk, herkesin kat' etmek zorunda olduğu bir 
yoldur. Felek, üzerinde bulunduğun köprüleri yıkmadan sen bu cihan köprüsünden deveni sür. Bu dünyaya bağlanma. Toprak tozdan, eşya kıvılcımdan başka bir şey değildir, hiçbirine bağlanma. Bu dünya sana kalmaz, kalıcı olmayan hiçbir şeye tapma!

Dâ'im be-to ber-cihân ne-mâned

Ân-râ me-perest k'ân ne-mâned(266 / 3)

Mecnûn, dünyadan göçer ve insanların serzenişinden kurtulur. Gelinin (Leylâ) yatağı üzerinde gözleri kapalı uykuya dalar. Ölüm uykusuyla bu dünyada bulamadığı huzura kavuşur. Bir ay hatta duyduğuma göre bir yıl oraya düşüp kalır. Mecnûn bir şah, vahşi hayvanlar da onun muhafızı gibidir, etrafını sarmışlar ve yuvalarını oraya yapmışlardır. Bu yırtıcıların korkusundan halk, oraya yaklaşamaz ve uzaktan baktıklarında arı gibi Mecnûn'un etrafına üşüşen hayvanların ona eşlik ettiklerini zannederler. $\mathrm{O}$ şahın ölüp gittiğinden, tacının ve kemerinin rüzgârla savrulduğundan, incinin toprağa karıştığından haberdar değildirler. Feleklerin dönmesiyle ortaya çıkan depremlerin onu toprağa saçtığından ve ondan geriye kalanın kemikten başka bir şey olmadığından haberdar değildirler. Vahşi hayvanlar, kimsenin oraya ayak basmasına izin vermez. İnsanlar, insanlıktan nasibini almamışken hayvanlardaki bu insaniyet ne gariptir. Velhâsıl, bir yıl sonra oradaki yırtıcı hayvanlar, ister istemez dağılıp giderler (Tarlan, 1990, s. 235-236):

Şod sâl gozaşte v'ân ded ü dâm

Âvâre şodend kâm u nâ-kâm （267 / 15）

Oradan geçenler mezara baktıklarında Mecnûn'un oraya düşüp öldüğünü ve geriye kalanın sadece kemikleri olduğunu görürler. Onu vefasından tanırlar. Araplar arasında bu efsanenin ünü yayılır ve herkes duyar:

Âvâze revâne şod be-her bûm

Şod der-Arab in fesâne ma'lûm (268 / 1)

Akrabalar, ileri gelenler, bütün dertliler toplanırlar. Çok ağlarlar, feryat ederler. O(Mecnûn), can incisini saçmış bir sadef gibi bembeyaz kalmıştır. Aşs ceylanından düşen üzeri tozlu, hoş kokular saçan misk gibidir. Üzerindeki tozu temizler ve sadef gibi içinde misk ezerler. Matem tutarlar. Gözyaşlarıyla yıkayıp temizler, topraktan toprağa verirler. Mezarı açar ve Leylâ'nın yanına gömerler:

Pehlû-geh-i dahme râ goşâdend

Der-pehlû-yı Leylîyeş nihâdend (268 / 9)

Leylâ ve Mecnûn, melâmet yolundan çıkıp kıyamete dek nazlı nazlı uyurlar. Onlar bu dünyada sözlerine sadık kaldıkları için, öbür âlemde aynı yatakta uyumaktadırlar. İki âşı̆̆ın kabri üzerine türbe yaparlar. O türbe bostanları kıskandıracak güzelliktedir ve bütün âşıkların ziyaret yeridir. Oraya gelen kimsesiz veya dertliler bütün kederlerinden kurtulurlar. Türbeye her gidenin dileği yerine gelir.

\subsection{Fuzûlı̂’de Mecnûn'un Ölüm Sahnesi:}

Leylâ’nın ölüm haberini alan Zeyd, hemen yollara düşer ve Mecnûn’a haber verir ve şöyle der: “Ey talihsiz! Yazık ki gayretlerin boşa gitti. Leylâ, sana hayat verdi, fani oldu, sen baki ol. O huri, cennete gitti.” Bunun üzerine Mecnûn, gönül yangınıla bir âh çeker. Öyle bir inler ki neredeyse sevgiliyi ecel uykusundan uyandıracaktır: 


\author{
Mecnûn ki haberden oldı âgâh \\ Sûz-ı ciğer ile çekdi bir âh \\ Az kaldı ki nâlesiyle dil-dâr \\ Ol hâb-1 ecelden ola bîdâr

Aklı başından gider, yere düşer. Kendine gelince ağlar, feryat eder. Zeyd'e sitemler eder: "Sana ne yaptım da canıma kast ettin, benim gibi çaresize kıydın, sitem ateşini canıma vurdun, bari bu günaha karşllık bir sevap işle, beni sevgilinin mezarına götür ve oranın mumu yap.”:

\title{
İlet meni yâr olan diyâra \\ Şem’ eyle meni mezâr-1 yâra
}

Mecnûn ve Zeyd, Leylâ'nın kabrine giderler. O gül yanaklının mezarını kucaklayan Mecnûn, başına topraklar saçar, göğsünü parçalar. Kabir taşı, kanlı gözyaşlarından la’l taşı gibi kıpkırmızı olur. Yeryüzü onun gözyaşlarıyla dolar. Akan sular yerin altına geçer ve Mecnûn, gözyaşıyla sohbet eder: "Ey ayrılık gecesinin karanlık yıldızı! O ay yüzlü burayı mekân edinmiş, sen durma, toprağa gir ve onu iste. Gör bakalım nerededir, o inci tanesi. Ayağını öpüp dualarımı ilet, bu yakarışlarla dolu sırrımı ona bildir.”:

Pâ-bûsın edüp yetür niyâzum

Bildür bu tazarru' ile râzum （2956)

Mecnûn, Leylâ imiş̧̧esine kabrindeki muma seslenir: "Ey mum! Benim gibi kara bahtlıdan bu sakınman, utanman niye? Gam kadehindeki meyi bir sen içmiştin bir de ben. Yoksa mest mi oldun, bu mecliste daha fazla duramadın. Bir süre yandın ama gönül yangınına dayanamayıp bıktın. Şehla gözlerin uykuya meyletti. Ey ay yüzlü! Yoldaş, yoldaşını bırakıp da gider mi?”:

$$
\begin{aligned}
& \text { Hem-râhum idün bu yolda ey mâh } \\
& \text { Hem-râhı koyup gider mi hem-râh(2963) }
\end{aligned}
$$

Mecnûn, toprağa seslenir: "Ey toprak! Feleklerle iftihar et, çünkü sana o inciyi verdi.” Mecnûn, yllana seslenir: "Ey yılan! Sevgilinin saçlarına dolanma, çünkü orada ağlayan bir gönül vardır." Mecnûn, karıncaya seslenir: "Ey karınca! Sevgilinin ben'ine taarruz etme, çünkü ona hicranlı canım bağlıdır." Mecnûn, ömre seslenir: "Ey ömür! Gel şimdi başa sen de, çünkü bu âlem gözüme karanlık oldu. Sevgili varken âlem güzeldi, eğer yoksa bu âlemde, kimse yok.”:

Ey ömr gel imdi başa sen hem

Kim çeşmime tîre oldı âlem ～(2967)

Mecnûn, canına seslenir: “Ey cân! Bu yorgun bedene veda et.” Ecele seslenir: "Ey ecel! Lutfet, kederimi al, sıkıntımı gider. Beni bu ıztıraptan kurtar, varlığıma yokluktan müjde ver. Aradaki engelleri kaldır, beni o sevgiliye kavuştur. Yâr, ağyarın olmadığı bir yerde bana vuslat teklif ediyor. Gitmezsem hatadır, senden bana bir meded yaraşır." Mecnûn, Rabbine seslenir: "Ey Rab! Bana cananım olmadan ne cihan ne cisim ne de can gerekir.":

Yâ Râb mana cism ü cân gerekmez

$$
\text { Cânânumsuz cihân gerekmez （2977） }
$$


Gönül sırlarını dile getiren Mecnûn'un isteği yerine gelir. Onu maksadına ulaştıracak Allah'ın yardımı yetişir. Emel bahçesinden güller derip ecel sürahisinden mey içer. Sevgilinin kabrini kucaklar ve orayı kendine can kını yapar. O kararsız âşık, "Leylâ" diyerek tatlı canını verir:

$$
\begin{aligned}
& \text { Leylî dedi verdi cân-ı şîrîn } \\
& \text { Ol âşılk-ı bî-karâr ü miskîn }
\end{aligned}
$$

Muhabbet, hayret makamı ile bir oldu. Sanki canı elindeydi ve hep bu anı gözetmişti. Sevdiği bu âlemde iken Mecnûn'un mekânı bu âlemdi. Ne zaman ki sevdiği bu âlemi terk etti, o da hemen terk etti:

Çün kıldı nigârı terk-i âlem

Bu âlemi terk kıldı ol hem

Mecnûn'un bu hâlini gören gamlı Zeyd, feleklere kadar çıkan feryatlar edip üstünü başını parçalar. O an öyle çok ağlayıp bağırır ki sesini duyan herkes oraya birikir. Kara bahtlı Mecnûn'un sevgilinin kabri üzerine yığılmış, sevgili için canını saçmış olduğunu görürler. Onun bu hâline herkes ağlar. Mecnûn'un cansız bedenine gusül abdesti aldırırlar. Sevdiğinin mezarını açarlar ve onu Leylâ'nın yanına koyarlar, defnederler. Ruh, ruha sırdaş olur, ten tene yoldaş. Engeller aradan kalkar ve vuslat gerçekleşir. Bir meclis, iki şahın mahfili olur; bir burç iki ay’a menzil olur. Kabrin üstüne işaret koyarlar, böylece bu hikâye cihana yayılır:

Kabr üstine koydılar nişâne

Fâş oldı bu mâcerâ cihâna

$(3008)$

Leylâ ve Mecnûn'un kabri geçen zamanla insanların muratlarını, arzularını söyledikleri, dileklerde bulundukları bir yer haline gelir. Zeyd, sadakat göstererek kabri tamir için ve etrafına binalar yapmak için çok uğraşır. Mezarın kandilini her zaman yanar halde tutar. Her zaman matemde olan Zeyd, ağlamalarını hiç eksik etmez. Kirpiği süpürge, gözyaşı su olur ve orayı temizler. Bu şefkatli dost bir gece sabaha karşı, kendinden geçer ve mezara yaslanıp uyuyakalır. Rüyasında bir bahçe ve yüzleri nurlu, gamsız, dertsiz iki ay parçası görür. Ağyar saldırısından kurtulmuş, mutlu, sevinçli, her birine binlerce meleğin hizmet ettiği iki ay parçası görür. Bunlar kimdir, nerenin padişahıdırlar, diye sorar. Derler ki; "Burası cennet bahçesidir; bu mübarek güruh, huri ve gılmanlardır. Bu iki mübarek yüzlü ay ise Mecnûn ve vefalı Leylâ’dır. Aşk vadisine tertemiz girip o paklıkla toprak oldukları için mekânları cennet bahçesi, bendeleri huri ve gılman oldu. Kedere ve derde sabredip kadere rıza gösterdikleri için vefasız dünyadan gidince dert ve kederden de kurtuldular. Zeyd, uyandıktan sonra gördüğü bu rüyayı halka anlatır. Böylece halkın buraya itikadı artar ve iki âşığın kabrini ziyaret etmek kanun olur:

$$
\begin{aligned}
& \text { Getdükde cihân-ı bî-vefâdan } \\
& \text { Kurtıldılar ol gam ü belâdan } \\
& \text { Halkun olup i’tikâdı efzûn } \\
& \text { Ol kabre ziyâret oldı kânûn }
\end{aligned}
$$

\section{Mukayese}

Nizâmî ve Fuzûlî’nin "Leylâ ve Mecnûn” adlı mesnevilerinde Mecnûn'un ölüm sahnesi yukarıda verilen olay örgülerinden de anlaşılacağı üzere birtakım farklılıklar ve benzerlikler barındırmaktadır. Buna iki 
şairin farklı üslup ve anlatımı da eklendiğinde meşhur bir hikâyenin hayal âlemlerine yansımaları daha net ortaya çlkmaktadır.

\subsection{Dil-Şekil-Yapı}

Mecnûn'un ölüm sahnesi, her iki şairde de Leylâ’nın vefatıyla bir bütünlük oluşturmaktadır. Nizâmî’de bu bölüm 109 beyitle "Leylânın mezarında Mecnûn'un ağlayıp inlemesi” ve "Leylâ’nın kabri üzerinde Mecnûn'un vefat etmesi” olarak iki ayrı başlıkta yer almaktadır. Fuzûlî̀de ise "Bu Mecnûnun Leylî vefâtından haber eşitdüğidür ve hasretle dünyâdan getdüğidür.” adlı tek başlıkla ve 109 beyitten meydana gelmektedir. Her iki şairin bu bölümü aynı beyit sayısında tamamlaması, Fuzûlî̀nin Nizâmî'den etkilenmesi yahut bir tesadüf olarak yorumlanabilir.

Mesnevi nazım şekliyle yazılan iki eserde kullanılan diller farklılık göstermektedir. Nizâmî eserini Farsça, Fuzûlî ise Türkçe yazmıştır. Hikâyeyi Nizâmî’den okuyan ve onu örnek aldığı söylenen Fuzûlî, kendi eserinde hayal ve anlam tekrarlarına düşmemiş ve çeviri yoluna gitmemiştir. Nizâmî, şiir dili olarak bilinen Farsça'nın ahengiyle üstünlük sağlamış gibi görünse de Fuzûlî, Türkçe'yi tüm azametiyle avantajlı bir hale getirmiştir. Sonuç itibariyle; iki eserdeki dil farklılı̆̆ı şairlerin hünerli anlatımları sayesinde herhangi bir zafiyet oluşturmamıştır.

\subsection{Olay Örgüleri}

Hikâyenin kahramanı Mecnûn'un ölümü, Nizâmî ve Fuzûlı̂nin eserinde farklılık ve benzerlikleriyle şöyledir:

Nizâmî'de, Leylâ'nın ölüm haberini alan Mecnûn hemen sevgilisinin kabrine koşar. Burada ağlar, feryat eder, Leylâ ile konuşur, dertlenir. Yanındaki yırtıcı hayvanlarla çöle döner. Sonra tekrar Leylâ'nın kabrine gelir. Orada ölmek için, Allah'a yalvaran Mecnûn’un duası kabul olunur.

Fuzûlî'de ise Leylâ'nın ölümünü önce Zeyd duyar, Mecnûn'un yanına gider ve ölüm haberini verir. Mecnûn'un aklı başından gider, Zeyd'e böyle bir haber getirdiği için sitem eder. İki arkadaş, Leylâ’nın kabrine giderler. Mecnûn, buradan hiç ayrılmaz. Gözyaşına, kabirdeki muma, Leylâ’nın içinde yattığı toprağa, canına, ecele ve Rabbine seslenir. Bunlarla dertleşir, sitemler eder, Leylâ'dan haberler almak ister ve Allah’a canını alması için dualar eder ve duası kabul olunur.

Nizâmî’de Mecnûn, Leylâ’nın ölüm haberini kimden aldı, nasıl aldı belli değildir. Sevdiğinin mezarına giderken yanında, arkadaş edindiği hayvanlardan başka kimse yoktur. Hatta ölürken de Mecnûn'un yanında söz konusu yırtıcı hayvanlardan başkası yoktur. Yalnızdır. Fuzûlî’nin Mecnûn’u, Leylâ'nın ölüm haberini dostundan yani Zeyd'den alır. Böyle kötü bir haber karşısında hesap soracağı, sitem edeceği bir dostun yanında olması şüphesiz Mecnûn için teselli edicidir. Leylâ’nın kabrine giderken Zeyd yine Mecnûn'u yalnız bırakmaz. Hatta ölüm anında ve öldükten sonra dahi kabrinin başında bekleyen vefalı bir dost olarak karşımıza çıkar.

Nizâmî’de, Mecnûn'un ölmeden önce ağzından çıkan son kelime "Ey dûst!" iken Fuzûlî’de Mecnûn, "Leylâ" diyerek can verir. Nizâmî̀nin metninde Mecnûn'un son sözü genel bir hitap ve adlandırma iken, Fuzûlî̀de sevgilinin doğrudan adının olması dikkat çeker. Bundan da Nizâmî̀nin, hikâyeyi sadece aktarma endişesi taşıdığı, Fuzûlî’nin ise, hikâye ve kahramanla özdeşleştiği sonucu çıkarılabilir. 
Nizâmî’nin Mecnûn'u öldüğünde yanında yırtıcı hayvanlar vardır. Bu sadık hayvanlar, bir sene boyunca Mecnûn'un başından ayrılmazlar. İnsanlar korkudan oraya yaklaşamadığı için geçen bir sene zarfında kimse zavallı âşığın öldüğünü anlamaz. Sonunda hayvanlar mezarın başından ayrılır ve Mecnûn'un öldüğü anlaşllır. Fakat ondan geriye kalan kemikleridir. İnsanlar, onun Mecnûn olduğunu vefasından anlarlar. Ancak böyle vefalı bir âşık, sevdiğinin mezarı başından ayrılmaz, diye düşünürler. Mecnûn'u Leylâ'nın yanına defnederler. Fuzûlî̀nin Mecnûn'u öldüğünde Zeyd, çok ağlar feryat eder. Zeyd'in bağırışlarını duyan insanlar, hemen mezarın başına toplanırlar. Mecnûn'u gasledip Leylâ'nın yanı başına gömerler.

“Mecnûn'un, Leylâ’nın kabri üzerinde ölmesi ve bir yıl boyunca orada kalması, sıradan bir ölüm yahut boş ve anlamsız bir ölüm değildir. Bu aşkın kahraman şehidi, diğer insanlar gibi yüzüne toprak örtüsünü çekmemiştir. Zahiren bu dünyadan göçmüş olsa bile bâtınen ebedî hayata ermiştir." (Settârî, 1366, s. 160) Elbette bu tespit, Nizâmî için geçerliyken Fuzûlî için geçerli değildir. Çünkü Fuzûlî’nin Mecnûn'u öldüğ̈̈nde yalnız değildir, öldüğü hemen duyulur ve her şey doğal seyrinde gelişir. Bu açıdan bakıldığında Fuzûlînnin Nizâmî̀ye göre daha gerçekçi olduğunu söylemek mümkündür.

Nizâmî'de bu iki âşı̆̆ın kabri tıpkı Fuzûlı̂'de olduğu gibi türbe haline getirilir. İnsanların, dertlilerin, muradı olanların uğrak noktası, ziyaretgâhı haline gelir. Ve bu aşk hikâyesi cihana yayılır. Fakat Fuzûlî’de Leylâ ile Mecnûn'un kabrini bekleyen, mumunu yakan, burayı türbe haline getiren, temizleyen ve bu türbenin başından ayrılmayıp günlerce aylarca matem tutan sadık bir dost vardır: Zeyd.

Celâl Settârî, "Mecnûn’un Aşk Hâlleri” adlı kitabında Nizâmî’nin eserinden yola çıkarak "ölüm teması" etrafında önemli tespitlerde bulunur. Leylâ ile Mecnûn'un öldükten sonra cennete gitmelerini, bu iki âşığın tıpkı çocuklar gibi dünyaya masum gelip masum gitmeleriyle ilişkilendirir. Kaldı ki Nizâmî ve Fuzûlî, Mecnûn'un ölümüyle bu tespiti zaten dile getirirler. İki şair de, söz konusu iki âşığın ayrıllğa ve cefaya bu dünyada sabrettiklerinin altını çizerek öbür dünyada vuslatı ve cenneti hak ettiklerini ifade ederler. Settârî, ayrıca şu cümleleri de ilâve eder ki çok yerinde bir tespit olduğunu söylemek gerekir: "Bu ölüm, öyle bir ölüm ki hayır ve bereket doludur. Çünkü masum âşılar, bu dünyadaki insanların, dertlilerin muratlarını yerine getirmek ve hastalara şifa vermek için vesile oluyorlar." (Settârî, 1366, s. 159-160) Yazar, Leylâ ve Mecnûn'un ölümlerinden sonra türbelerinin, dileği olanlara bir ziyaretgâh ve bu insanların dertlerine derman buldukları bir yer haline gelmesini kasteder.

Fuzûlî̀nin eserinde Leylâ ile Mecnûn'un kabrinden ayrllmayıp gece gündüz bekleyen Zeyd, bir gün yorgunluktan başını mezara dayar ve uyuyakalır. Rüyasında, Leylâ ile Mecnûn'u cennet bahçesinde görür. Huri ve gılmanlar bu iki aşığa hizmet etmektedir. Zeyd, bu rüyayı herkese anlatır ve insanların bu türbeye inancı daha da artar. Nizâmî’de bu bölüm yoktur. ${ }^{8}$ Böyle bir farklılık, Nizâmî’nin bulunduğu coğrafyadaki sosyal yapının trajik sonlara alışkın olduğunu, Fuzûlî coğrafyasında ise aşk hikâyelerinin sonlarının mutlulukla bitmesi temayülünde olduğunu gösterebilir.

\section{3. Üslup ve Anlatım}

Birçok şairin kaleminde tazelenip yeni bir ruha bürünen meşhur hikâye, Nizâmî ve Fuzûlînnin farklı üslup ve anlatımlarıyla ayrı birer hikâyeye dönüşmüş gibidir. Mecnûn'un ölüme adım adım ilerlediği sahneler ve bu arada içinde bulunduğu hissiyatın aktarımı iki şairin bakış açısını, kurgulama tekniğini,

8 Nizâmî’nin mesnevisine ilaveler yapan şair-i İlhâkî, Zeyd’in rüyasını Fuzûlî’ninkine benzer bir şekilde kaleme almıştır. Fakat daha önce de bahsedildiği üzere bu bölümlerin Nizâmîye ait olup olmadığı kesinlik arz etmediği için mukayeseye dâhil edilmemiştir. 
anlatım tarzını ve üslûbunu net bir şekilde ortaya koymaktadır. Tüm bu hususiyetlerin aksettiği ifadelerin mukayesesi şöyledir:

Leylâ’nın ölüm haberini aldığı anda Mecnûn’un verdiği tepki Nizâmî’de, "Bulutlar gibi için için gürledi." Fuzûlî'de ise "Öyle bir inledi ki neredeyse sevgiliyi ecel uykusundan uyandıracaktı." cümleleriyle ifade edilir. Her ikisinde de üzüntü ve kederden kaynaklanan bir inilti söz konusudur. Nizâmî, âşıla bulut arasında hem ses hem de sonrasında gelen yağmur-gözyaşı benzerliği kurarak sanatlı bir anlatım sergilemiştir. Fuzûlî de aynı şekilde ve hemen hemen aynı anlamı ihtiva eden fakat farklı ve mübalağalı bir anlatımla, âşığın o anki kederinin yoğunluğunu vermek adına uyanılması imkânsız olan ecel uykusundan uyandıracak kadar şiddetli inleyişini ifade etmiştir.

Mecnûn'un henüz ölmeden ruhunun derinliklerine kadar ölümü hissettiği bölüm, Leylâ'nın ölümüdür. Dolayısıyla sanatlı anlatımlar, bu bölümde daha fazla ön plana çıkmıştır. Nizâmî’de Mecnûn, ağlarken bir yandan da toprağın altındaki Leylâ ile konuşur, dertleşir. Bu tek taraflı musahabede Mecnûn, sevgilisinin yokluğuna üzüldügünü anlatan ifadeler kullanır. Soru cümleleri ile anlatımı tesirli hâle getiren Nizâmî, sevdiğinin ölümünü kabullenemeyen Mecnûn’a söylettiği; “Toprak eziyet ediyor mu? Bu karanlık mezarda ne yapıyorsun? Misk tanesi gibi ben’in, o ahu gözlerin ne hâlde? Hangi gözler görüyor seni? Bu mağaranın içinde neler yapıyorsun?” gibi cümlelerle kahramanın yaşadığı dramı tüm boyutuyla gözler önüne sermektedir. Ardından hikâyeye dâhil olan Nizâmî, "Bu cümleleri söyledi ve ağladı, dövündü...” gibi ifadelerle şair-anlatıcı olarak kendini hissettirmektedir.

Fuzûlî’de Mecnûn, sevgilinin yokluğuna üzülmekle birlikte onun rahatını da düşünmektedir. Toprak da dâhil olmak üzere toprağın altındaki ölünün karşılaşabileceği yılana, karıncaya da seslenerek Leylâ’ya ve dolayısıyla kendine zarar vermemelerini istemektedir. Çünkü gönlü, canı maşukun yanındadır. Ona gelecek kötülük ve dert, ben-sen kaygısından bertaraf olmuş Mecnûn’undur.

Fuzûlî, Leylâ'nın ölümünden sonra Mecnûn'un duygularını dile getirirken çoğunlukla hitap cümlelerine başvurur. Nizâmî’nin soru cümleleriyle yarattığı tesiri, Fuzûlî hitap cümleleriyle gerçekleştirir. Mecnûn, aynı konu etrafında gözyaşına, muma (Leylâ), toprağa, yılana, karıncaya, ömre, canına, ecele ve son olarak da Rabb’ine seslenir. Her sesleniş, kahramanın hissiyatını okuyucuya aktarmaktadır. Meselâ; “Ey mum/Leylâ! Bir süre yandın, ama gönül yangınına dayanamayıp bıktın. Yoldaş, yoldaşını bırakıp gider mi? Ey toprak! Sana o inciyi/Leylâ’yı verdiği için feleklerle iftihar et. Ey yılan! Sevgilinin saçlarına dolanma, çünkü orada ağlayan bir gönül vardır.” gibi cümleler âşığın matemini yansıtmakla kalmayıp acısını da derinden hissettirmektedir.

Hikâyede ölüm sahnesinin gerçekleştiği mekân olarak kullanılan "kabir", her iki şairde çeşitli benzetmelerle tasvir edilmiştir. Nizâmî, "kabir" için "kan dalgası, yatak, kuyu, karanlık sular, mağara", Fuzûlî ise "meclis, burc, can kını, la’l taş”" ifadelerini kullanmıştır.

Nizâmî, Mecnûn'un ağzından Leylâ için "ay, hazan vurmuş taze gül, hazine, su, toprağın gelini”, Fuzûlî ise "gül yanaklı, ay yüzlü, mum, inci tanesi, şah" ifadelerini kullanmıştır. Mecnûn'u tasvir ederken Nizâmî; "hazine bekçisi yılan, dağdan inen sel, zemzem suyu, yorgun bir karınca, yaralı bir yılan, sadef, misk" kelimeleriyle teşbih etmiştir. Fuzûlî, Mecnûn için "talihsiz, kara bahtll, şah, ay" ifadelerini kullanmıştır.

Mecnûn, ölümü arzuladığı için dua eder. Nizâmî’nin Mecnûn’u şöyle der; “Ey her şeyi yaratan Hâlık! Beni bu mihnetten kurtar ki sevdiğime kavuşayım. Ruhumu özgür bırak, canımı al; bu sıkıntılardan beni 
Two Poets, One Lover on The Way to Death / Y. Akkuş (p. 21-36)

kurtar.” Söz konusu dua cümlesinde, Mecnûn istediği şeyi doğrudan bir anlatımla dile getirir. Hâlbuki Fuzûlî’nin Mecnûn'u öncesinde ömrüne, ecele ve cana hitap edip arzusunu hissettirir. Son olarak da Allah'a dua eder: "Ey Rab! Cananım yoksa bana ne cihan ne cisim ne de can gereklidir." Dolaylı bir anlatımla ölümü isteyen Fuzûlînnin Mecnûn'u, bunu bilinçli bir şekilde yapmış olmalıdır. Ölümü istemek, Rab katında hoş karşılanan bir şey değildir. Bu sebeple Mecnûn; "Aradaki engelleri kaldır, beni o sevgiliye kavuştur. Yâr, ağyarın olmadığı bir yerde bana vuslat teklif ediyor.” gibi ifadelerle ölümü istemek için haklı sebepleri olduğunu anlatmaya çalışmıştır.

Aşk ve ölümün bu kadar iç içe girdiği ve birbirinden ayrılmaz olduğu Leylâ ve Mecnûn hikâyesini Fuzûlî, tasavvufî bir anlayışla kaleme almış ve "beşerî bir aşkı tasavvufî bir eksene oturtmuştur". (Turinay, 1996, s. 226) Nizâmî̀nin de tasavvufî öğeleri kullandığı fakat bunu yaparken hikâyenin geneline yansittığı söylenebilir. "Gayet bol kullanılan tasavvufî terimlere rağmen, Nizâmî’nin eseri gene de beşerî kalmaya devam eder” (Turinay, 1996, s. 227).

Beşerî aşktan ilâhî aşka yönelen Mecnûn'un ölümü, tasavvufî olarak derin manalar içermek zorundadır. Bu durum Nizâmî'de görülmezken Fuzûlî’de ikilikten vahdete, muhabbetten hayret makamına geçiş şeklinde kendini göstermektedir. Mecnûn, öldükten sonra Fuzûlî der ki; "Muhabbet, hayret makamı ile bir oldu. Sevdiği ne zaman bu âlemi terk etti, o da terk etti.” Bu misralar, Leylâ'nın ölümü ile âşı̆̆ın(Mecnûn'un) maddî âlemi terk edişi ve hayret makamına geçişini anlatmaktadır. Âşşı, ölüm denen vuslatla ikilikten kurtulur ki bu da Mecnûn ölüp Leylâ’nın yanına gömüldükten sonra Fuzûlî tarafından şöyle dile getirilir: "Bir meclis iki şahın mahfili oldu. Bir burç iki aya menzil oldu." Tasavvufun en mühim düsturu gerçekleşmiş ve ölüm ile gelen vuslat sayesinde "sen-ben” ortadan kalkmış ve kesretten vahdete erişilmiştir.

Nizâmî’nin Leylâ ve Mecnûn'unda şiir öne çlkar ve hikâyeye galip gelirken, Fuzûlî'de dil ve anlatımın bütün imkânlarının hikâyeyi başarıya ulaştırmak ve hikâyede bütünlüğü sağlamak olduğu görülmektedir. Fuzûlî’nin anlatışından ve üslûbundan doğan muhtevanın etkileyiciliği tasavvuftan ya da hikâye vakasından kaynaklanmamaktadır. Bu ancak şairin sanatı ile izah edilebilir. Fuzûlî, eserine kattığı tasavvufî eda ve iyi kurgulanmış bir anlatıcı sayesinde hikâyenin beşerî ve tasavvufî olmak üzere iki ayrı düzlemde okunmasını sağlamaktadır (Turinay, 1996, s. 228, 243).

Nizâmî, Mecnûn’un öldüğünü sözü uzatmadan şu cümle ile dile getirir: "O da bu dünyadan geçti/göçtü.” Fuzûlî ise sanatlı bir anlatımla Mecnûn'un ölümünü şöyle ifade eder: "Emel bahçesinden güller derip ecel sürahisinden mey içer."

Her iki şair de hikâyeyi aktarmayı zaman zaman bir kenara bırakıp şair-anlatıcı tavırlarını hissettirerek 'kendi' bakış açılarını sergilemektedir. Meselâ; Nizâmî Mecnûn'un ölümünden hemen sonra okuyucuya nasihatler eder. Ölümü kastederek; "Bu yoldan geçmeyen var mıdır? Yokluk herkesin geçmek zorunda olduğu bir yoldur... Bu dünya sana kalmaz, kalıcı olmayan hiçbir şeye tapma!” cümlelerini sarf eder. Hatta devamında bir kahraman anlatıcı edasıyla Mecnûn için söylediği; "Bir ay hatta duyduğuma göre bir yıl oraya düşüp kaldı." cümlesi dikkat çekicidir. Özellikle 1. tekil şahsın kullanıldığı "duyduğuma göre" ifadesi, Nizâmî’yi şair-anlatıcı yani ilâhî bakış açısından bir anlık da olsa çıkararak hikâyeye dâhil eder.

Fuzûlî de Mecnûn'un ölümünün ardından anlatıcı olarak devreye girer; fakat şairin bu müdahil oluşu Nizâmî’de olduğu kadar bariz ve kendini hissettirici değildir. Mecnûn, can verdikten sonra şair-anlatıcı (Fuzûlî), çok çileler çekmiş bir âşığın ölümünü ilâhî bakış açısıyla yorumlar gibidir: "Muhabbet, hayret 
makamı ile bir oldu. Sanki canı elindeydi ve hep bu anı gözlemişti. Sevdiği bu âlemde iken Mecnûn'un mekânı bu âlemdi. Ne zaman ki bu âlemi terk etti, o da hemen terk etti.”

Mecnûn'un defnedilmesi, söz konusu ölüm sahnesinin bir parçası olarak karşımıza çıkmaktadır. Bu bölümde iki şairin üslup ve anlatımında da birtakım farklılıklar görülmektedir. Nizâmînin mesnevisinde; "Mecnûn'un ailesi, akrabaları ve bütün dertliler toplanıp ağlaşır, feryat ederler. Gözyaşlarıyla âşı̆̆a gusül abdesti aldırırlar ve topraktan toprağa verirler.” ifadeleri yer almaktadır. Ayrıca Nizâmî, Mecnûn'un cansız bedenini betimlerken, ölen insanın kanı çekilmesi ve beyaz oluşuna atfen, onu can incisini saçmış bembeyaz bir sadefe; aşkla hayat bulan bir âşı̆̆ın ölümünün ardından bıraktığı hoşluklara atfen, aşk ceylanından düşen üzeri tozlu miske benzetmektedir. Şair, bu iki sanatlı anlatımı şöyle birbirine bağlar: "Miskin üzerindeki tozu temizlediler ve sadefin içinde misk ezdiler." Bu cümle, insanların Mecnûn’u defnetmek üzere hazırlamasını ifade etmektedir.

Fuzûlînnin mesnevisinde Mecnûn'un defnedilmesinde kullanılan üslûp ve anlatım, Nizâmî̀de olduğu kadar sanatlı değildir. Fuzûlî bu bölümü doğrudan aktarır: "Sevgili için canını saçan Mecnûn’u gördüklerinde herkes ağlar. Cansız bedenine gusül abdesti aldırırlar.”

Mecnûn'un Leylâ'nın yanına gömülme sahnesini Nizâmî ve Fuzûlî, hemen hemen aynı anlatımla ve olduğu gibi aktarırlar: "Mezarı açtılar ve Leylâ’nın yanına koydular." Sonrasında ise Nizâmî; "Onlar, bu dünyada sadık kaldıkları için, öbür âlemde aynı yatakta uyuyorlardı." cümlesiyle o anı tasvir eder ve ölümle vuslata erdiklerinin haberini verir. Aynı zamanda gerçek aşkın ancak sadık kalınarak olunabileceğinin de mesajını verir.

Fuzûlî ise, iki âşığın yan yana gömülmesinden sonraki durum tasvirini, sanatlı bir anlatımı tercih ettiği şu cümlelerle yapar: "Ruh, ruha sırdaş oldu; ten, tene yoldaş. Engeller aradan kalktı ve vuslat gerçekleşti. Bir meclis, iki şahın mahfili oldu. Bir burç, iki aya menzil oldu.” Fuzûlî de tıpkı Nizâmî gibi ölümle birlikte engellerin ortadan kalktığını ve vuslatın gerçekleştiğini dile getirir. Şair, bu ebedî kavuşmayı bir mecliste iki şah, bir burçta iki ay benzetmeleriyle süsler.

\subsection{Zaman ve Mekân}

Mesnevilerde zaman kavramı genellikle belirsizdir ve şairler hikâyenin zamanını net bir şekilde pek ortaya koymazlar. Mecnûn'un ölümünün ailesi ve diğer insanlar tarafından duyulması Nizâmî’de, olay anından bir ay yahut bir yıl sonra gerçekleşir. Hâlbuki Fuzûlî̀de, ölüm gerçekleşir gerçekleşmez, Zeyd tarafından insanların haberdar olması sağlanır. Hem ölüm haberinin duyulması hem de Mecnûn'un defnedilmesi Nizâmînnin hikâyesinde bir ay yahut bir yıl sonra gerçekleşmiş olur.

Her iki şairde de ölüm anı Leylâ'nın kabri üzerinde gerçekleşir. Mekân çöl ve Leylâ'nın kabridir. Nizâmî’nin Mecnûn’u, bir ara Leylâ’nın kabrinden ayrılıp çöllere gitse de tekrar buraya geri döner.

\section{Sonuç}

Asırlarca zirvede kalmayı başaran, her daim talep gören Leylâ ve Mecnûn hikâyesi, ihtiva ettiği olay örgüleri, kahramanları ve konusu ile 'aşk-ölüm' ekseninde kurgulanmıştır. Ölümsüz bir aşk hikâyesi, önce maşuk daha sonra âşığın ölümüyle ebedî vuslata yol açmıştır.

Mecnûn'un ölüm sahnesinde, asıl mesele elbette Mecnûn'un hâlleri, hissettikleri ve dilinden dökülenlerdir. Bu yaralı âşı̆̆ı, ölüme yaklaştıran Leylâ’nın ölümüdür. Nizâmî ve Fuzûlî, Mecnûn’u 
Leylâ’nın ölümüne şahit kılar, bu dayanılmaz kaybı zavallı âşığa yaşatırlar. Dolaysıyla Mecnûn'un ölümü arzulaması, bunun için dualar etmesi Leylâ'nın yokluğu ile ortaya çıkar. Aslında Mecnûn, ölümüyle aşkını ölümsüz kılar; yani fani olanı baki kılar. Tüm bunlara tasavvufî unsurların dâhil edilmesi ve beşerî aşkın ilâhî aşka devşirilmesi, her iki âşığın ölümüyle anlamlı hâle gelir.

Nizâmî ve Fuzûlî, Mecnûn’un ölüm sahnesini kaleme alırken hikâyenin bütünlügünü sağlamak ve tesirli bir bitiş sunmak adına hünerlerini sergilemişlerdir. Biri Fars ve diğeri Türk edebiyatına ait olan bu iki şair, birbirine çok yakın neredeyse ortak bir şiir geleneğinden beslenmişlerdir. Fakat kültürel ve toplumsal farklılıklar ile dil ve üslup farklılıkları aynı hikâyenin ayrı ayrı yorumlanmasına sebep olmuştur. Söz konusu edebî gelenek, şairlerin sanatlı anlatımlarında ve hayal dünyalarında kendini hissettirmektedir. Nizâmî, kullandığı dil ve üslupla şiirini ön plana çıkarmakta, Fuzûlî ise kusursuz bir kurgu ve tahkiye ile hikâyeciliğini zirveye taşımaktadır.

Mecnûn'un ölüm sahnesi, genel hatlarıyla her iki şairde aynılık arz etmekle birlikte farklılıklar daha çok tahkiye etme, üslup ve anlatım ekseninde meydana gelmektedir. Özellikle gözlem, anlatma, aktarma, üslup, kurgulama ve tahkiye açısından mukayese edildiğinde, Fuzûlînnin tasavvufu kararında öncelediği, aklî ve hissî, insanî ve ilâhî dengeyi doğru kurguladığı, şair-anlatıcı tavrını okuyucuya hissettirmeden ortaya koyduğu ve Nizâmî̀ye göre daha gerçekçi olduğu görülmektedir.

\section{Kaynakça}

Açıköz, N. (1998). Fuzûlî, İstanbul: Timaş.

Açıkgöz, N. (1987). Leylâ ile Mecnûn Mesnevisinnin Yapısı, Ankara: Milli Kültür, S. 59, s. 39-43.

Ayan, H. (2014). Leylâ vü Mecnûn/Fuzuli, İstanbul: Dergâh.

Destgerdî, H.; Hamidiyân, S. (1389). Hakîm Nizâmî-i Gencê̂ Leylî vü Mecnûn, Tahran: Neşr-i Katre.

Doğan, Muhammet Nur (2015). Fuzûlî Leylâ ve Mecnûn, İstanbul: Yelkenli.

İpekten, H. (2015). Fuzûlî Hayatı-Sanatı-Eserleri / Bazı Şïrlerinin Açılamaları, Ankara: Akçă̆.

Kanar, M. (2007). "Nizâmî-i Gencevî", İslâm Ansiklopedisi, C. 33, İstanbul: Türkiye Diyanet Vakfi.

Levend, A. S. (1959). Arap, Fars ve Türk Edebiyatlarında Leylâ ve Mecnûn Hikâyesi, Ankara: Türk Tarih Kurumu.

Mazıoğlu, H. (1992). Fuzûlî ve Türkçe Dîvânindan Seçmeler, Ankara: Kültür Bakanlı̆̆ı.

Onan, N. H. (1956). Fuzûlî Leylâ ile Mecnûn, İstanbul: Maarif Basımevi.

Rousseau, A. M. ve Cl. Pichois (1994). Karşılaştırmah Edebiyat, Çeviren: Yrd. Doç. Dr. Mehmet Yazgan, İstanbul: Milli Eğitim Bakanlığı.

Servetiyân, B. (h. 1376). Endîşehâ-yı Nizâmî-i Gencê̂, Tebriz: İntişârât-ı Aydın.

Settârî, C. (h. 1366). Hâlât-ı Aşk-ı Mecnûn, Tahran: İntişârât-ı Tûs.

Tarlan, A. N. (1990). Leylâ ile Mecnûn-Nizâmî, İstanbul: Milli Eğitim Bakanlığı.

Turinay, N. (1996). Klasik Romana ve Leylâ vü Mecnûn'a Dair, Fuzûlî Kitabı-50o. Yılında Fuzûlî Sempozyumu Bildirileri, İstanbul: İBB Kültür İşleri Daire Başkanlığı, s. 223-244.

Yazıcı, T. (2003). "Leylâ ve Mecnûn”, İslâm Ansiklopedisi, C. 27, İstanbul: Türkiye Diyanet Vakfı. 